\title{
Impact of Counselling Practicum on Trainees in University of Ilorin Nigeria
}

\author{
Shuaib Abolakale Muhammed
}

Ph.D., Department of Counsellor Education, Faculty of Education, University of Ilorin, Nigeria, muhammed.sa@unilorin.edu.ng

Oniye Abdulrazaq Olayinka

Ph.D., Department of Counsellor Education, Faculty of Education, University of Ilorin, Nigeria, oniye.ao@unilorn.ed.ng

Alabi Samson Olamilekan

Department of Counsellor Education, University of Ilorin, Ilorin, Nigeria, alabisukanmi@gmail.com

Practicum is an important aspect of the counsellor education programme which is aimed at helping student counsellors develop practical skills and other qualities required for professionalism. The study investigated the impact of counselling practicum on trainees in University of Ilorin, Nigeria. The descriptive research design was adopted for the study. The population of the study consisted of all student counsellors in the Department of Counsellor Education, University of Ilorin. The simple random sampling technique was used to select 250 respondents selected from both the full-time undergraduate and postgraduate programme. A researcher developed questionnaire tagged "Impact of Counselling Practicum Questionnaire (ICPQ)" was used to gather data from the respondents. The questionnaire was validated by lecturers in Counsellor Education Department University of Ilorin and was also subjected to reliability test using a Pearson's Product Moment Correlation formula and a reliability coefficient of 0.68 was obtained. The data obtained were analysed with percentages, mean ranking and t-test statistic. The findings revealed that the counselling practicum has high impact on counsellortrainees. For instance, it assists trainees to; develop self-confidence in relating with clients, learn how to apply counselling skills maximally, and discover their strengths as student counsellors. A significant difference was found on the impact of counselling practicum on trainees based on respondent's level of education but no significant difference was found on the basis of gender. The implication is that trainees at different level need practicum experience to achieve professional development. It is recommended that undergraduate and postgraduate counsellortrainees, irrespective of gender, should be assisted to develop requisite skills, ethics, and values of carrying out their professional roles optimally in the counselling profession.

Keywords: counselling practicum, impact, trainees, university of Ilorin, teaching

\section{INTRODUCTION}

Practicum is a very important aspect of Guidance and Counselling Education Programme. Practicum activities enable the trainees to understand and synthesize the interrelationship among courses to make a meaningful use of them. Practicum is normally conducted after students have completed most of their course work in the counsellor preparation programme According to Zakaria (2013), practicum is a supervised practical experience that enables student (counsellor) to develop counselling skills and integrate professional knowledge.

Citation: Muhammed, S. A., Olayinka, O. A., \& Olamilekan, A. S. (2019). Impact of Counselling Practicum on Trainees in University of Ilorin Nigeria. Anatolian Journal of Education, 4(2), 61-68. https://doi.org/10.29333/aje.2019.427a 
The practicum performs several functions in the professional training programme of counsellors. For instance, practicum period enables the trainees to have an opportunity to integrate the courses they have been taught in the programme (Misigo, 2014). It is designed to provide student-counsellors with closely supervised counselling practice at approved field sites in either schools, or non-school settings, such as hospitals, industries, government agencies, and so on. The goal of practicum is to give studentcounsellors practical experience in guidance and counselling (Nwachuku, 2009).

The practicum period provides closely supervised field work experience in guidance and counselling during which theoretical skills, techniques, and organizational strategies are practiced in an approved setting. According to Nwachuku (2009), the setting could be inside a school, an industry, a financial institution, rehabilitation centre, hospital setting or any other human institutional establishment as may be deemed appropriate for the fulfilment of the trainees' professional aspiration/capacity building or competency development.

For counsellors in training, the practicum programme is designed to assist trainees acquire skills and behaviors, which if displayed, would show the counsellors' mastery of techniques and knowledge in their prospective field. In fact, when skills are properly used, it builds the confidence of clients and this consequently develops into a relationship between the counsellor and the counselee. Furthermore, the practicum exercise would expose trainees to different caliber of clientele (client) during practicum for instance; the clients may include children if the exercise is done in a pre-school or primary school setting, adolescents, and adults if done in post-primary school setting. The clients may also include individuals who are experiencing or planning to successfully circumnavigate personal, social, vocational, family, educational, financial and/or interpersonal relationship crisis and thus require professional guidance and counselling. Therefore, counselling practicum exposes the trainee to real life counselling experience under close supervision by experienced professional guidance counsellors.

The counselling practicum grooms these counsellor-trainees for success in the counselling profession. Generally, practicum in counsellor education regardless of the variation in its duration, field of placement or scope is expected to provide learning opportunities for trainees to acquire practical skills in counselling. The duration of counselling practicum in Nigeria is generally between 6 and 12 weeks for counsellor education programmes at the bachelor's degree, master degree, and doctoral degree level of guidance and counselling. There could be one variation or the other in duration and depth of counselling practicum in most other countries of the world when compared with Nigeria which is understandable given inherent difference in the socio-cultural milieu and educational philosophy of different group of people from one country to the other. The University of Maryland counselling practicum and internship is a 16 week-long programme (2014). The practicum program at the Texas University Counselling Centre lasts for a period of 9 months (Moore, 2014). The University of Southern Maine has a counselling practicum class, with a two- and half-hour classroom instruction and a one-hour individual supervision session each week, beginning from the second week of teaching session. In other places, the graduate counselling practicum programme normally lasts for one full academic session (Willchnganz, 2014).

The relevance of counselling practicum to the professional development of a trainee is enormous as it is also designed to build self-efficacy in practitioners at a very early stage of their training life. Practicum assists the trainees to develop self-confidence in relating with clients, building good communication skills, developing problem solving skills, and identifying their weaknesses and strengths as potential counsellors (Ford \& Alao, 2009).

In Nigeria, practicum activities in counsellor training programme have not received the desired attention required due to factors ranging from problems of achieving legal professionalism, limitations to school practices, poor attitude of practitioners towards professionalism, lack of conducive environment for practice, lack of awareness of the importance of practicum, poor supervision, and lack

Anatolian Journal of Education, October $2019 \bullet$ Vol.4, No.2 
zeal by counsellor educators in emphasizing the importance of practicum to trainees' professional development among others (Yahaya, 2016).

In the light of these challenges, many of the counsellor-trainees in Nigeria may lack one or two requisite skills and competencies needed to render professional service to their clients. Invariably, this reduces the availability of competent manpower required for professional development of counselling practice. This may inform the reason why Omoegun (2001) posited that counsellor training without practicum would not allow the trainees to develop good knowledge of self (strengths and weaknesses as an individual), their work (knowledge of requirements and demands of the profession), and ways of merging their potentials with the requirements of their work.

As much as practicum is an important aspect of counsellor training programme worldwide, there seems a paucity of empirical studies on issues relating to counselling practicum in Nigeria although few studies have been carried out within and in other parts of the world. For instance, in Nigeria, Udoh and George (2014) worked on the relevance of counselling practicum in counsellor education programmes in Nigeria. The authors explored the variations in field placement approaches and practicum duration. They also furthered an understanding of the skills, knowledge and competencies expected from and for the counsellor-trainee during the practicum exercise; discussing extensively how the practicum may assist trainees to develop professional skills and competencies and also advanced key performance criteria that may be employed in gauging the success of every counselling practicum exercise

Misigo (2014) worked on student-counsellors' perception of practicum experience as a way to improve guidance and counselling programme in Moi University, Kenya. The sample comprised of 16 respondents who had participated in practicum. A questionnaire comprised of both closed and openended items was used to collect data. The findings revealed that student-counsellors perceived support from the school management where they practiced as a way to improve guidance and counselling programme.

It is evident that the counselling practicum is core to a counselling training programme. The focus of this study therefore, is to examine:

1.the level of awareness among trainees about the impact of counselling practicum on their professional development and,

2.the impact of counselling practicum on trainee's professional development.

\section{Research Questions}

The following questions were raised to guide the study

1.What is the level of awareness among trainees about the impact of counselling practicum in University of Ilorin?

2. What is the impact of counselling practicum on trainees as perceived by student counsellors in the University of Ilorin, Nigeria?

\section{Research Hypotheses}

The following null hypotheses were also formulated to guide the study:

$\mathbf{H}_{01}$ : $\quad$ There is no significant difference in the perception of postgraduates and undergraduate's perception on the impact of counselling practicum on trainees in University of Ilorin.

$\mathbf{H}_{\mathbf{0 2}}$ : There is no significant difference in male and female students' perception of respondents on the impact of counselling practicum on trainees in University of Ilorin. 


\section{METHOD}

\section{Research Design}

The research design adopted for this study was a descriptive survey method. The survey method is describing, records, analyses and interprets existing conditions or phenomenon as they naturally exist. The design was considered appropriate because it enabled the researcher to describe the view of respondents of this study on the impact of counselling practicum on trainees in university of Ilorin, Nigeria.

\section{Participants/Sampling}

The population comprised of all the 755 registered counsellor-trainees in the Department of Counsellor Education, Faculty of Education, University of Ilorin. The sample consisted of 250 counsellor-trainees who are enrolled for both undergraduate and postgraduate in the Department of Counsellor Education, University of Ilorin. The purposive sampling technique was used to select counsellor trainees who are on full time postgraduate programme and undergraduates who are in the final year. This is because the final year undergraduate and the postgraduates in the department would have had experiences of different practicum activities and supervision over the years of their stay as students.

\section{Data Collection Tool}

A structured questionnaire entitled "Impact of Counselling Practicum Questionnaire (RCPQ)" was used to gather data for the study. The questionnaire consists of two sections, A and B. Section A contained the demographic data of the respondents (gender and level of study). Section B contains 20 items on respondents' perception of relevance of counselling practicum in preparing counsellortrainees for professionalism. The instrument was patterned after a four-point Likert-type rating scale of: SA-Strongly Agree, A-Agree, D-Disagree, and SD-Strongly Disagree. The respondents were expected to rate the items as applicable to them in each section. The instrument was validated by five lecturers in the Department of Counsellor Education, University of Ilorin. The corrections of the experts were used to modify the questionnaire items before administering the final draft. The instrument was further subjected to reliability test using the test retest method. The scores of the two administrations was correlated using Pearson's $r$ and the result yielded a reliability coefficient of 0.68. This magnitude was considered high enough for the instrument to be reliable. The questionnaire forms were administered to the respondents by the researcher. The respondents filled forms immediately and collection was made on the spot to ensure $100 \%$ return rate.

The highest possible score any respondent could obtain was 80 (4 x 20), while the lowest obtainable score is $20(1 \times 20)$. Therefore, the range is $60(80-20)$. Thus, the midpoint of the range was $30(60 / 2)$. The cut-off point was $80-30$ or $20+30$, which in either case were 50 . Thus, respondents who obtained score ranging from 50-80 would be considered as having high awareness of the impact of counselling practicum on preparing counsellor-trainees for professionalism and those whose scores fall between 49 and below would be considered as having low awareness.

\section{Data Analysis}

The data generated in section A (demographic data) were displayed using percentages. Hypotheses 1 and 2 were analyzed using $t$ tests. All hypotheses in the study were tested at 0.05 level of significance.

\section{FINDINGS}

The section presents the findings and discussion on the study. The main purpose of the study was to examine the impact of counselling practicum on trainees in University of Ilorin, Nigeria. 
Table 1

Percentage Distribution of Respondents Based on Gender and Level of Study

\begin{tabular}{lcl}
\hline Variable & Frequency & Percentage $(\%)$ \\
\hline Gender & & \\
Female & 130 & 52.0 \\
male & 120 & 48.0 \\
Total & 250 & 100.0 \\
Level of Study & & \\
$\quad$ Undergraduate & 191 & 76.4 \\
$\quad$ Postgraduate & 59 & 24.6 \\
Total & 250 & 100.0 \\
\hline
\end{tabular}

Based on the distribution of respondents by their demographic characteristics; it was revealed that $48.0 \%$ (120) of the respondents were male while $52 \%$ (130) of the respondents were female. This indicates that female participated more than male in the study. The table further shows that $76.4 \%$ (191) of the respondents were undergraduates, while $23.6 \%$ (59) of the respondents were postgraduate students. This indicates that respondents at the undergraduate level participated more in the study?

Research Question 1: What is the awareness level of respondents on the impact of counselling practicum on trainees in the University of Ilorin, Nigeria?

Table 2

Percentage Distribution of Respondents' Awareness Level of Counselling Practicum on Trainees

\begin{tabular}{lll}
\hline Awareness Level & Frequency Count & Percentage \\
\hline High & 191 & 76.4 \\
Low & 59 & 23.6 \\
Total & 250 & 100.0 \\
\hline
\end{tabular}

The result on table 2 revealed that majority $(76.4 \%)$ of respondents has high awareness of the impact of counselling practicum on trainees. This means that counsellor trainees have high awareness of the impact of counselling practicum on trainee's professional development

Research Question 2: What is the impact of counselling practicum on trainees as perceived by student counsellors in the University of Ilorin, Nigeria?

Table 3

Mean and Rank Order Analysis of Respondents' View on the Relevance of Counselling Practicum in Preparing Counsellor-Trainees for Professionalism

\begin{tabular}{|c|c|c|c|}
\hline No. & Item & Mean & Rank \\
\hline 1 & It helps in developing confidence in relating with clients & 3.66 & $1^{\text {st }}$ \\
\hline 2 & It assists student counsellors in learning how to apply Counselling skills maximally. & 3.49 & $2^{\text {nd }}$ \\
\hline 14 & It helps students to discover their strengths as student counsellors & 3.42 & $3^{\text {rd }}$ \\
\hline 4 & It helps to improve the communication skills of student counsellors & 3.40 & $4^{\text {th }}$ \\
\hline 7 & It helps student counsellors in learning how to utilize appropriate Counselling techniques to solve problems. & 3.40 & $4^{\text {th }}$ \\
\hline 13 & It helps students to discover their weaknesses as student counsellors & 3.39 & $6^{\text {th }}$ \\
\hline 3 & It makes students develop the competence needed to handle real counselling situation. & 3.38 & $7^{\text {th }}$ \\
\hline 9 & It helps would-be counsellors to relate counselling theories learnt to practice in their own environment. & 3.32 & $8^{\text {th }}$ \\
\hline 11 & It helps student counsellors to learn how to achieve counselling goals. & 3.31 & $9^{\text {th }}$ \\
\hline 18 & Help student counsellors to work through counselling stages effectively. & 3.31 & $9^{\text {th }}$ \\
\hline 5 & Expose student counsellors to peculiar challenges in the locality & 3.30 & $11^{\text {th }}$ \\
\hline 8 & It helps in reducing initial anxiety among student counsellors & 3.30 & $11^{\text {th }}$ \\
\hline 10 & The experience in practicum has contributed to professional development. & 3.30 & $11^{\text {th }}$ \\
\hline 19 & Provide student counsellors with constructive feedback of them counselling performance & 3.30 & $11^{\text {th }}$ \\
\hline 12 & It helps student counsellors to learn how to set counselling goals. & 3.29 & $15^{\text {th }}$ \\
\hline 20 & Provides student counsellors with the opportunity of using new and different techniques when appropriate & 3.28 & $16^{\text {th }}$ \\
\hline 15 & It helps in developing potential problem-solving skills of student counsellors. & 3.26 & $17^{\text {th }}$ \\
\hline 6 & It helps students to assume full role of a professional Counsellor & 3.25 & $18^{\text {th }}$ \\
\hline 17 & Provides student counsellors with knowledge of documenting case record on clients. & 3.24 & $19^{\text {th }}$ \\
\hline 16 & Provides students with opportunity to participate in professional activities e.g. staff meeting, work shop, etc & 3.16 & $20^{\text {th }}$ \\
\hline
\end{tabular}

Anatolian Journal of Education, October $2019 \bullet$ Vol.4, No.2 
The result was analyzed using mean and rank order to rate the items contained in the questionnaire on the impact of counselling practicum. Items 1, 2, and 14 were ranked as the top 3 items. Item 1, ranked first with a mean score of 3.66. Item 2 with mean score of 3.49 ranked second while item 14 with mean score of 3.42 ranked third. Items 4 and 7 ranked fourth with mean score of 3.40 were the least ranked items. Since all the items ranked above 2.50 , it could be concluded that the respondents perceived counselling practicum to be highly impactful on trainee's professional development

\section{Hypothesis Testing}

Hypothesis 1: There is no significant difference in the perception of respondents on the impact of counselling practicum on trainees based on level of study

Table 4

Respondents' Perception of Impact of Counselling Practicum on Trainees based on Level of Study

\begin{tabular}{lllllll}
\hline Level of Study & $N$ & Mean & $S D$ & $d f$ & $t$-value & $p$-value \\
\hline Undergraduate & 191 & 66.15 & 6.81 & 248 & $2.56^{*}$ & .011 \\
Postgraduate & 59 & 68.61 & 5.02 & & & \\
\hline
\end{tabular}

The result on table 4 showed a significant $t$-value of 2.56 and a P-value of 0.01 less than the alpha value. This means that there is a significant difference in respondent's perception on the impact of counselling practicum on trainees based on level of study. Therefore, trainees of different level of study have divergent perceptions. On this basis, the null hypothesis was rejected.

Hypothesis 2: There is no significant gender difference in the perception of respondents on the impact of counselling practicum on trainees.

Table 5

Respondents' Perception on the Impact of Counselling Practicum in Preparing Counsellor-Trainees for Professionalism

\begin{tabular}{lllllll}
\hline Gender & $N$ & Mean & $S D$ & $d f$ & $t$-value & $p$-value \\
\hline Male & 120 & 66.82 & 7.013 & 248 & .217 & .829 \\
Female & 130 & 66.65 & 6.026 & & & \\
\hline
\end{tabular}

The results revealed a non-significant $t$-value of .217 and a p value of .828 greater than the alpha value. This means that there is no significant gender differences in respondent's perception on the impact of counselling practicum on trainees Therefore trainees of different gender have similar perceptions On this basis, the null hypothesis was not disconfirmed.

\section{CONCLUSION, DISCUSSION AND SUGGESTIONS}

Based on the finding, it was concluded that concluded that majority of the trainees in University of Ilorin had high awareness that counselling practicum has positive impact on trainee's professional development. It was further concluded that trainees perceived counselling practicum to be highly valuable in developing self-confidence when relating with clients, learning how to apply counselling skills maximally, and in discovering their strengths as student counsellors. A significant difference was found on the impact of counselling practicum on trainees based on respondent's level of education but no significant difference was found on the basis of gender.

\section{DISCUSSION}

The study revealed that the student counsellors in University of Ilorin perceived counselling practicum to be highly relevant in preparing counsellor-trainees for professionalism. The most rated impacts of practicum to trainee's professionalism included that it assist trainees to develop self-confidence in relating with clients, assists them in learning how to apply counselling skills maximally, and to 
discover their strengths as student counsellors. This result is consistent with those of Carlo (2014), whose findings suggested that with continued development and ongoing evaluation, the new training model (counselling practicum) may realize its full potential as avenue through which students' counselling skills, collaboration, and human relations skills can be developed together. The finding of this study also reveals that counselling practicum is perceived by respondents to be capable of helping students to discover their strengths as student counsellors, helps would-be counsellors to relate counselling theories learnt to practice in their own environment and also, the experience in practicum has contributed to professional development. This to an extent is also in agreement with another study by Rodrigues (2013) which showed that elements in counselling practicum and strength which is acquired in practicum training and mastery of theory among trainee counsellors will aid the production of excellent counsellors in this profession.

The study further showed a significant different in the perception of respondents on relevance of counselling practicum on trainee's professionalism based on level of study. The difference noted in the perception of the respondents may be due to inherent difference in work experience of postgraduate student counsellor and their level of maturity as compared to their undergraduate counterpart. The perception of a postgraduate student counsellor (some of who are already practicing counsellors) on the relevance of counselling practicum may be more informed by their work experience as compared to an undergraduate student counsellor who may see the counselling practicum programme as just a means of getting good grades. Maturity can also be a contributing factor as to the fact that most postgraduate student counsellors are older in age and have experience more than undergraduate student counsellors.

Finally, the study found that there is no statistically significant gender difference in respondents' perception of the relevance of counselling practicum to trainees' professionalism. This finding is in line with DeLorge (2012), who explored counselling practicum students experience in departmentbased and community-based settings and discovered that there is no significant difference in the respondents' experience based on the practicum setting, supervision modalities, or number of supervision modalities on the basis of respondents' gender. The reason for this could be because practicum activities are not gender sensitive; it can be undertaken by both genders at any point in time hence the similarity noted in the result.

\section{Suggestions}

Based on the findings of the study, it was suggested that

1.Counsellor-trainees should be encouraged by professional counsellors to actively, and truthfully participate in the counselling practicum programme

2.Undergraduate and postgraduate counsellor trainees of both genders should be assisted to develop requisite skills, ethics, and values of carrying out their professional roles optimally in the counselling profession. Also, more emphasis should be laid on exposure of trainees to counselling practicum sessions while practicum periods should be delinked from teaching practice.

3.Workshops and seminars should be organized to sensitize students at different level of study about the relevance of counselling practicum to professional development of counsellors.

Proper supervision should also be put in place by both (university) supervisors as well as on-site supervisors (which mostly are the school counsellors) so that the student counsellors can be monitored and corrected when practicing their counselling skills with clients. 


\section{REFERENCES}

American Counselling Association (2010). Consensus definition of counselling. Retrieved from www.counselling.org.

Carlo, C. (2014). Practicum in counseling: A new training model. Lanigan Elementary school, Fulton, New York; Jean M. Casey State University of New York, Oswego DC: $\quad$ ERIC Clearinghouse on Teacher Education. ERIC Document Reproduction.

DeLorge, M. C. (2012). An exploration of counselling practicum students' experience in departmentbased and community-based settings. University of New Orleans Theses and Dissertations.

Ford, R. C., \& Alao, K. (2009). Practical counselling: A guidebook for the diagnosis and treatment of normal human behavior. West Sussex: Strategic Insight Publishing.

Misigo, B. L. (2014). Student-counselors' perception of practicum experience: A case of Moi University bachelor of education guidance and counselling students. International Academic Journal of Social Sciences and Education, 1(3), 1-11.

Moore, P. (2014). Graduate practicum training program: Counseling center. Texas State University. Retrieved from http://www.counseling.txstate. edu/training/internship0.html.

Nwachuku, D. N. (2009). Guidance and counseling practicum in pre-primary, primary and secondary schools. A guide to guidance counselors: Methods, skills, techniques and competencies. Calabar, Nigeria: University of Calabar Press.

Omoegun, O.M. (2001). A functional approach to practicum in guidance and counselling. Ikorodu: BabSheriff.

Rodriguez, C. (2013). Practicum in counselling. Retrieved from www.counsellingpracticum.org. Service No. ED 316548.

Udoh, N. A. \& George, I. N. (2014). The relevance of counselling practicum in counsellor education programmes in Nigeria. International Journal of Development and Sustainability, 7(15), 26-37.

Willchnganz, B. F. (2014). The graduate counseling practicum programme of the Camosun College. Retrieved from ww.merianwebs_Individual_Counselling_Practicum/Counselor_Education,Ater.com/../illiterate.

Yahaya, L.A. (2016). Professionalization of counselling in Nigeria. University of Ilorin press.

Zakaria, M. (2013). Of practicum students in the use of theories while conducting counseling sessions. International Journal of Business and Social science, 4(1), 184-94. 